University of Nebraska - Lincoln

DigitalCommons@University of Nebraska - Lincoln

1949

\title{
Mechanical Transmission of a Plant Tumor Virus to an Insect Vector
}

Karl Maramorosch

Myron K. Brakke

University of Nebraska-Lincoln

L. M. Black

Follow this and additional works at: https://digitalcommons.unl.edu/plantpathpapers

Part of the Plant Pathology Commons

Maramorosch, Karl; Brakke, Myron K.; and Black, L. M., "Mechanical Transmission of a Plant Tumor Virus to an Insect Vector" (1949). Papers in Plant Pathology. 181.

https://digitalcommons.unl.edu/plantpathpapers/181

This Article is brought to you for free and open access by the Plant Pathology Department at DigitalCommons@University of Nebraska - Lincoln. It has been accepted for inclusion in Papers in Plant Pathology by an authorized administrator of DigitalCommons@University of Nebraska - Lincoln. 


\title{
Mechanical Transmission of a Plant Tumor Virus to an Insect Vector ${ }^{1}$
}

\author{
Karl Maramorosch, ${ }^{2}$ M. K. Brakke, and L. M. Black
}

Brooklyn Botanic Garden, New York

Most plant viruses transmitted by leafhoppers have not been demonstrated to be infective in extracts. The virus dealt with in this paper eauses tumors in certain susceptible plants, is carried by leafhoppers, and like others in that group has proven difficult to detect in extracts. It is our purpose to recount briefly the variety of methods that failed to transmit the virus and to report on the success of insect-to-insect transmission by injection.

The virus, known as wound-tumor virus, Aureogenus magnivena Black (R), is transmitted from plant to plant by the leafhoppers Agalliopsis novella (Say), Agallia constricta Van Duzee, and Agallia quadripunctata (Provancher). Attempts by the authors to transmit the virus

1 This work was supported in part by a grant from the American Cancer Society in accordance with a recommendation by the Committee on Growth, National Research Council.

2 Fellow in Cancer Research, American Cancer Society. Present address: The Rockefeller Institute for Medical Research. New York City. 
mechanically from plant to plant have been made, using various methods of inoculation, both with untreated juice from infected plants and also after the addition of materials to the juice to alter the osmotic pressure, $\mathrm{pH}$, and oxidation-reduction potential with the aim of stabilizing the virus. Juice has been rubbed onto the leaves and injected into the stems and erowns of plants by different techniques. Several species of susceptible plants have been used in these experiments, but an infection has never been obtained by any of these methods. The inoculation of plants with juices from infective insects also failed to produce infection, even though such juice was proved to have infective virus when tested by the successful technique described here. Leafhoppers fed on juices from diseased plants, from viruliferous insects, and on concentrates of these juices prepared by high speed centrifugation did not become infective. It is possible, of course, that more extensive trials with these procedures or variations of them might yield positive results.

Storey (5) was the first to transmit a plant virus from insect to insect by inoculating virus-free vector leafhoppers, Cicadulina mbila Naude, with juice from insects carrying maize-streak virus, Fractilinea maidis (Holmes) McKinney (3). Using fine glass capillaries, Black (1) transmitted the aster-yellows virus (Chlorogenus callistephi $\mathrm{H}$. var. vulgaris $\mathrm{H}$.) by injecting juice from virulifer. ous into nonviruliferous leafhoppers (Macrosteles divisus Uhler). In view of these earlier successes, it seemed logical to attempt transmission of the virus by injecting healthy vector leafhoppers with extracts from insects carrying wound-tumor virus.

Three hundred and fifty nonviruliferous leafhoppers (Agallia constricta Van Duzee) were caged on crimson clover plants (Trifolium incarnatum L.) showing pronounced symptoms of wound-tumor disease and were kept there for four weeks at about $25^{\circ} \mathrm{C}$. Maramorosch had previously (4) obtained good transmission of the virus at $25^{\circ} \mathrm{C}$ with this vector, after a minimum incubation period in the insect of two weeks. The insects were then collected and ground at $0^{\circ} \mathrm{C}$ with an equal weight of $0.25 \mathrm{M} \mathrm{NaCl}$. The suspension was centrifuged at 3500 rpm for $5 \mathrm{~min}$, and the supernatant used without further dilution for the injection of 28 virus-free nymphs. The solution was drawn up into a fine glass capillary, and a small amount forced into the insect through a puncture made in the abdomen with a glass capillary. Twelve of the 16 insects which survived the injection proved to be infective when tested on crimson clover plants. Although no controls were included in this experiment, the results are considered significant because there were no accidental infections with this virus in the greenhouse during the course of this experiment or the two previous years.

A second experiment was carried out to confirm these results as well as to obtain a first approximation of the dilution end point. An extract of viruliferous insects was prepared as in the first experiment, and $0,10^{-1}, 10^{-2}$, 10-3, and 10-4 dilutions were made with $0.25 \mathrm{M} \mathrm{NaCl}$. Groups of $20-30$ insects were inoculated with each dilution, and an equal number of uninoculated insects were kept as controls. All insects were tested individually on two sets of crimson clover plants over a period of two months, and the plants were then observed in the greenhouse for an additional period of two months. None of the control insects became infective, but some insects in oculated with each dilution of viruliferous insect extract up to and including $10^{-3}$ did. There was a long incubation period before inoculated insects were able to infect healthy plants with wound-tumor virus.

These experiments show that wound-tumor virus can be detected in extracts from insects, and the experiments also make possible the determination of some of the physical and chemical properties of the virus. The fact that three leafhopper-transmitted plant viruses have proved transmissible by this method of insect inoculation suggests that the method may suceed in certain instances where other techniques have failed.

\section{References}

1. BLACK, L. M. Phytopathology, 1941, 31, 120.

2. - Amer. J. Bot., 1945, 32, 408.

3. Holmes, F. O. The filterable viruses. Suppl. 2. Bergey's Manual of determinative bacteriology (6th Ed.). 1948. Baltimore: Williams and Wilkins. Pp. 1127 1286.

t. Maramorosch, K. Phytopathology, 1949, 39, 14.

J. Storey, H. H. Proc. roy. Soc. Lond., Ser. B., 1933, 113, 463. 